\title{
Drug Enrichment of Commercial Poultry Feeds and Human Health in the Tropical Developing Countries
}

\author{
By Adé A. Ojeniyı
}

Gastro-Enterology Division, Department of Medicine, Rigshospitalet (National University Hospital), Copenhagen, Denmark.

\begin{abstract}
Ojeniyi Ade, A: Drug enrichment of commercial poultry feeds and human health in the tropical developing countries. Acta vet. scand. 1989, 30, 133-139. - Eighty per cent of Enterobacteriaceae isolates from battery poultry exhibited drug resistance in a survey among university and commercial poultry flocks. These birds, being a source of human food, may serve as an important reservoir for human pathogenic drug-resistant enteric organısms. Feeds used on University and Commercial poultry farms were found to be inhibitory to standard test organisms - Oxford strain of Staphylococcus aureus and Escherichia coll K 12 J5 NA+ Lac-. Feed additives, which purportedly were mineral and vitamin supplements, were found to be highly laden with antibacterials, a quantitative estimation of which revealed that one of them, termed A \& D Crumbles contaned as much as 3000 (three thousand) $\mu \mathrm{g}$ of antıbiotic per $\mathrm{g}$, while another feed additive known as ADVIT contained $130 \mu \mathrm{g}$ of antibiotic per $\mathrm{g}$ of the feed supplement. These are routinely added to poultry feeds, a practice which may easily lead to development of drug resistance among enteric pathogens that may, in turn, reach humans and complicate therapy of human bacterial infections. This may be of a considerable public health significance.
\end{abstract}

feed additives; drug resistance.

\section{Introduction}

During an epidemiological survey of Enterobacteriaceae among poultry reared under various conditions in some parts of Nigeria, $80 \%$ of the isolates were found to exhibit drug resistance (Ojeniyl 1980). As these birds serve as sources of food for humans, drug resistance among enteric pathogens could have adverse public health effects. In countries with intensive poultry husbandry practice, like the Scandinavian countries, Britain and the United States of America, incorporation of antibiotics and chemotherapeutics in the birds' feeds has been practised for quite some time. However, it has been shown in these countries that a large reservoir of antibiotic resistant Escherichia coli exists in poultry (Siegel et al. 1975), with these organisms being regularly excreted in large numbers in their faeces (Howe et al. 1976), while drug resistant organisms can reach man through poultry products (Harbour et al. 1978). These drugs which have been given to animals extensively either as growth promoters or for prophylaxis, must account for the large number of resistant Escherichia coll present in the gastro-intestinal tract of poultry (Siegel et al. 1974, Smith 1974, Linton 1977, Harbour et al. 1978, Edit 1979, Ojeniyi 1980, Holmberg et al. 1984a). Poultry husbandry, like other livestock husbandry in developing countries, is still in its infancy. However, the poultry industry in these countries is already aiming 
at the trends of large flock rearing systems of Europe and America. As may be expected, the same problems of drug resistance would arise, especially as there is no effective control of drug use in the tropical developing countries. Such drug resistance problems may reach alarming proportions as plasmid-mediated transmissible resistance factors are involved (Ojeniyi 1980). It was considered desirable therefore, to examine the feeds available in Nigeria, for example, for the contents of antimicrobial agents, in the wake of the appearance among battery poultry of multiply resistant Escherichia coli resistant to Streptomycin, Sulphonamide and Tetracycline.

\section{Materials and methods}

Feed lots at the University of Ibadan Teaching and Research Poultry Farm, Olaogun Commercial Poultry Farm and University of Ife Institute of Agricultural Research and Training's Bora Poultry Farm were sampled over a period of $21 / 2$ years. All 3 poultry establishments have their own feed mills. The following feeding stuffs were sampled and examined for antibacterial activity.

University of Ibadan:

Feeding stuffs: Chicks' mash Growers' mash Layers' mash Breeders' mash

Commercial Farm:

Feeding stuffs: Growers' mash Breeders' mash

Feed additives: A \& D Crumbles

Broilers' mash

Vitality Chicks' mash

Goldlay hybrid layers' mash

University of Ife:

Feeding stuffs: Chicks' mash

Broilers' mash

Feed additives: A \& D Crumbles

Breeders' mash

\author{
A \& D Crumbles \\ ADVIT \\ Agricare Mix \\ Chick Formula
}

Antibacterial activity in feeding stuffs and feed additives

Twenty-five g portions of each feeding stuffs and $10 \mathrm{~g}$ portions of feed additives were weighed out into $250 \mathrm{ml}$ conical flasks. Quarter strength Ringer's solution was added to each flask and the mixture was allowed to stand for several minutes. This extraction procedure was repeated using Todd Hewitt Broth to ensure that inhibition of the test organisms was not due to the acidity of the medium. The mixture was filtered, first through a filter paper to remove particles and obtain a clear extract, and later through a Seitz filter with a grade EK Asbestos Pad for sterilisation. Each sterilised filtrate was pipetted into sterile round bottomed test tubes and double dilutions up to 1 in 32 were prepared. Young broth cultures of each of two test organisms - Oxford strain of Staphylococcus aureus and Escherichia coli $\mathrm{K}$ 12 J5 NA+ Lac- were prepared and the concentrations of viable bacterial cells in each case was adjusted by use of a nephelometer to match McFarland's Standards Numbers 0.5 and 0.25 . Each of the two test organisms was subsequenlty drop inoculated into the 
various filtrate dilutions. Test tubes containing broth only and organisms only were also prepared. All the test tubes were hereafter incubated for $24 \mathrm{~h}$ at $37^{\circ} \mathrm{C}$.

Qualitative and Quantitative analysts of Feeding Stuffs for Antıbiotics

This was carried out according to the procedures enumerated in the European Common Market Gazette (1972). A spectrum of bacteria at various hydrogen ion concentrations and at different temperatures was employed in the detection and identification of antibiotics present in animal feeds. The following organisms were used:

Staphylococcus aureus

Micrococcus flavus BR

Escherichia coli

Micrococcus flavus

Bacıllus subtilis

Micrococcus luteus DHSR

Staphylococcus epidermidis

Bacıllus cereus TR + Penicillinase

Bacillus cereus TR

Streptooccus faecalls

Bacillus cereus

Extraction: Three-gram samples of various feeding stuffs were agitated for $15 \mathrm{~min}$ with $15 \mathrm{ml}$ solvent consisting of methanol and phosphate buffer. This was centrifuged and $0.1 \mathrm{ml}$ of each extract pipetted into a well of $10 \mathrm{~mm}$ in diameter which was bored in sensitivity agar in plates of $200 \mathrm{~mm}$ in diameter.

Plate preparation: Assay culture medium, consisting of the following, was prepared and boiled:

glucose $1 \mathrm{~g}$
peptone $10 \mathrm{~g}$
dried meat extract $1.5 \mathrm{~g}$
yeast extract $3 \mathrm{~g}$
agar $15 \mathrm{~g}$
water to $100 \mathrm{ml}$.

Half of this volume was adjusted to $\mathrm{pH} 6$ and the other half to $\mathrm{pH} 8$. Both were sterilised at $120^{\circ} \mathrm{C}$ for $15 \mathrm{~min}$ and cooled to $50^{\circ} \mathrm{C}$ hereafter. $100 \mathrm{ml}$ of the $\mathrm{pH} 6$ medium were taken and to this volume was added $1 \mathrm{ml}$ penicillinase solution capable of inactivating 1000 i.u. penicillin per $\mathrm{ml}$ within $1 \mathrm{~h}$ at $37^{\circ} \mathrm{C}$. Meanwhile bacterial suspensions were prepared and added to each antibiotic solution. These were inoculated into bore holes of $10 \mathrm{~mm}$ in diameter made in petri dish agar. The test was set up as an agar diffusion test on plates with 4 concentration levels of standard solutions $\left(S_{8}, S_{4}, S_{2}, S_{1}\right)$ and four concentration levels of each extract $\left(\mathrm{U}_{8}, \mathrm{U}_{4}\right.$, $\left.\mathrm{U}_{2}, \mathrm{U}_{1}\right)$. Each plate contained all 4 concentrations of standard and 4 concentrations of extract. Four inoculations of each of standard and each of extract were made such that 32 inhibition zones were recorded for each test. Thus, extracts of A \& D Crumbles and ADVIT, supposedly mineral and vitamin supplements, were inoculated into the bore holes. The plates were incubated overnight at $30^{\circ} \mathrm{C}$ and at $37^{\circ} \mathrm{C}$.

\section{Calculation of Antibiotic contents}

The diameter of inhibition zones were measured by projection. Inhibition zones, in $\mathrm{mm}$ were plotted against the logarithms of concentrations. Straight lines were drawn through the plotted points of the standards and of the extracts. The logarithms of antibiotic activity were calculated according to the formula:

$$
\begin{aligned}
& \frac{\left(\mathrm{U}_{1}+\mathrm{U}_{2}+\mathrm{U}_{4}+\mathrm{U}_{8}-\mathrm{S}_{1}-\mathrm{S}_{2}-\mathrm{S}_{4}-\mathrm{S}_{8}\right) \times 0.602}{\mathrm{U}_{4}+\mathrm{U}_{8}+\mathrm{S}_{4}-\mathrm{S}_{8}-\mathrm{U}_{1}-\mathrm{U}_{2}-\mathrm{S}_{1}-\mathrm{S}_{2}} \\
& \mathrm{U}=\text { Unknowns (A \& D Crumbles and } \\
& \quad \text { ADVIT) } \\
& \mathrm{S}=\text { Standards (EEC Values) }
\end{aligned}
$$




\section{Results}

Filtrates of all the feeding stuffs used on all 3 farms, including Chicks' mash were inhibitory to the 2 test organisms. Table 1 shows the results of the tube dilution tests. Of the Feed Additives, A \& D Crumbles and Chick Formula were most inhibitory to the test organisms with growth inhibition taking place even at the highest dilution prepared: 1 in 32. Agricare Mix was found to be inhibitory at all dilutions except at 1 in 32; at this dilution, inhibition was rather inconclusive. ADVIT was the least inhibitory of all the Feed additives tested; inhibition being inconclusive even with the undiluted filtrate. Table 2 shows the performance of a spectrum of test organisms against a range of antibiotics, and the effect of 2 of the Feed Additives on these organisms. It will be seen from this table that A \& D Crumbles were inhibitory to most of the test organisms, while ADVIT was active against only 4 of them. The results of the quantitative estimation of Tetracycline content in A \& D Crumbles and in ADVIT are reflected in Tables $3 \mathrm{~A}, 3 \mathrm{~B}$ and $3 \mathrm{C}$. Trials at various assumed concentration levels and calculations showed that the content of Tetracyc- line is about $3000 \mu \mathrm{g}$ per $\mathrm{g}$ of $\mathrm{A} \& \mathrm{D}$ Crumbles while that of ADVIT was about $130 \mu \mathrm{g}$ per $\mathrm{g}$ of this feed supplement.

\section{Discussion}

Despite the denial of feed enrichment with antibiotics by the management of the Universities' and Commercial Poultry Farms, antibacterial agents were detectable in appreciable quantities in the Feed Additives. It was claimed that the supplements added to feedlots were made up exclusively of vitamins and minerals: thus A \& D Crumbles and ADVIT were said to be no more than vitamins $A$ and $D$. This practice was thought to prevent disease, promote growth and offset stresses due to vaccinations against Newcastle Disease, Fowl Pox and Fowl Typhoid. In industrialised countries with intensive poultry husbandry, many problems have arisen from feed enrichment with antibacterial agents (Quarles et al. 1977, Linton 1977, Smith 1978, Holmberg et al 1984a, b), the most important of which are development of resistance against such drugs and the phenomenon of resistance factor transfer to otherwise drug-susceptible organisms. The public health aspects center around the possibility

Table 1. Inhibition dilutions of feeding stuffs and feed additives.

\begin{tabular}{lccccccccccc}
\hline & $\begin{array}{c}\text { Chicks' } \\
\text { Mash }\end{array}$ & $\begin{array}{c}\text { Brolers' } \\
\text { Mash }\end{array}$ & $\begin{array}{c}\text { Growers' } \\
\text { Mash }\end{array}$ & $\begin{array}{c}\text { Layers' } \\
\text { Mash }\end{array}$ & $\begin{array}{c}\text { Breeders' } \\
\text { Mash }\end{array}$ & $\begin{array}{c}\text { A \& D } \\
\text { Crumbles }\end{array}$ & ADVIT & $\begin{array}{c}\text { Agncare } \\
\text { Mix }\end{array}$ & $\begin{array}{c}\text { Chick } \\
\text { Formula }\end{array}$ & $\begin{array}{c}\text { Broth } \\
\text { Control }\end{array}$ & $\begin{array}{c}\text { Organism } \\
\text { Control }\end{array}$ \\
\hline B: St. au. & 16 & - & 16 & 16 & 16 & 32 & 1 & 16 & 32 & - & - \\
B: E. coli & 16 & - & 16 & 16 & 16 & 16 & 1 & 8 & 32 & - & - \\
C: St $a$ au. & 16 & 2 & 8 & 2 & 4 & 32 & 1 & - & - & - & - \\
C: E. coll & 8 & 2 & 4 & 4 & 2 & 32 & - & - & - & - & - \\
F: St. au. & 8 & 8 & - & - & 4 & 32 & - & - & 32 & - & - \\
F: E. coll & 8 & 4 & - & - & 4 & 16 & - & - & 32 & - & - \\
\hline
\end{tabular}

B = University of Ibadan Teaching and Research Poultry Farm

C = Olaogun Commercial Poultry Farm

F = University of Ife, Institute of Agricultural Research \& Training Bora Poultry Farm.

St. au. = Staphylococcus aureus 
Table 2. Detection and identification of antibiotics by means of a bacterial spectrum.

\begin{tabular}{|c|c|c|c|c|c|c|c|c|c|c|c|c|}
\hline & $\mu \mathrm{g} / \mathrm{ml}$ & 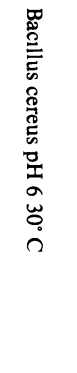 & 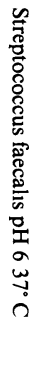 & 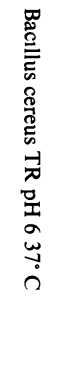 & 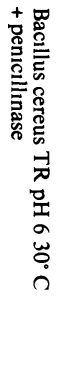 & 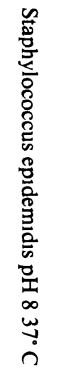 & 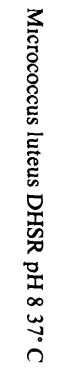 & 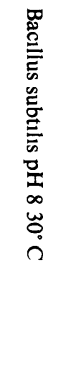 & 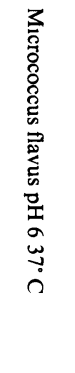 & 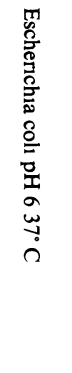 & 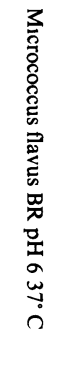 & 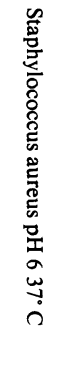 \\
\hline Chlortetracycline & 0.2 & + & + & - & - & - & $-*$ & -* & $-*$ & - & + & $-^{*}$ \\
\hline Penicillın & $0.41 . \mathrm{u} . / \mathrm{ml}$ & - & - & + & - & - & + & - & + & - & + & $-^{*}$ \\
\hline Streptomycin & 0.8 & + & - & + & + & - & - & + & - & + & - & + \\
\hline Bacitracin & 10 & - & + & - & - & - & + & - & + & - & - & - \\
\hline Flavomycin & 0.2 & + & - & + & + & - & - & - & - & - & - & - \\
\hline Virgınıamycin & 1 & + & + & + & + & + & + & - & + & - & - & - \\
\hline Spiramycin & 1 & + & + & + & + & - & + & + & + & - & - & - \\
\hline Oleandomycin & 4 & + & + & + & + & $-*$ & + & + & + & - & - & -* \\
\hline Neomycin & 10 & + & + & + & + & + & + & + & + & + & + & + \\
\hline Furazolidone & 10 & + & - & + & + & + & - & + & $-^{*}$ & $-^{*}$ & + & + \\
\hline Nitrovın & 10 & + & + & + & + & + & - & + & - & - & + & + \\
\hline Monensin $\mathrm{Na}$ & 8 & + & - & + & + & -* & - & $-^{*}$ & - & - & + & $-*$ \\
\hline Chloramphenicol & 40 & + & + & + & + & $-^{*}$ & -* $^{*}$ & $-^{*}$ & $-^{*}$ & + & - & $-^{*}$ \\
\hline \multirow[t]{2}{*}{ ADVIT } & & 17.3 & - & 15.5 & - & 17.8 & - & - & 21.8 & - & - & - \\
\hline & & + & - & - & - & + & - & - & - & - & - & - \\
\hline \multirow[t]{3}{*}{ A \& D Crumbles } & & 41.0 & - & 16.6 & - & 17.5 & 42.8 & 27.3 & 43.3 & 32.5 & 44.7 & 39.2 \\
\hline & & + & - & - & - & + & + & + & + & + & + & + \\
\hline & & & \multicolumn{10}{|c|}{ Inhibition zones in millimeters } \\
\hline
\end{tabular}

of transmission to humans of such drug resistant organisms that arise as a direct consequence of antibacterial agents' use. More serious still is the possibility of spread of resistance factors among enteric bacteria that may be pathogenic for humans. The tropical developing countries are characterised by poor environmental sanitation, while at the same time, antibiotics are readily available without a prescription and are freely used in the belief that these drugs confer advantages enumerated above. It is obvious therefore, that public health may be jeopardised as a widespread drug resistance can complicate the therapy of many human bacterial infections. Since veterinary and pharmacy laws and regulations prohibit the use of drugs except on prescription, a stricter enforcement of drug legislation is necessary to avoid the problems of drug resistance which, in the tropical developing countries, may very readily assume epidemic proportions and pose hazard for public health. 
Table 3 A. Quantitative analysis of antibacterial agent content in A \& D Crumbles at an assumed content level of $100 \mu \mathrm{g} / \mathrm{ml}$.

\begin{tabular}{llllll}
\hline \multicolumn{5}{c}{ Inhibition zones in millımeters } & Average \\
\hline U 1 & 34.9 & 35.3 & 34.5 & 35.6 & 35.1 \\
U 2 & 36.2 & 36.6 & 35.9 & 35.1 & 36.0 \\
U 4 & 38.7 & 36.2 & 37.5 & 37.7 & 37.5 \\
U 8 & 40.3 & 39.4 & 39.1 & 39.8 & 39.6 \\
S 1 & 24.4 & 24.6 & 25.1 & 24.8 & 24.7 \\
S 2 & 26.8 & 27.0 & 26.0 & 27.5 & 26.8 \\
S 4 & 29.8 & 29.1 & 29.2 & 29.4 & 29.4 \\
S 8 & 31.5 & 31.2 & 32.2 & 29.8 & 31.2 \\
\hline
\end{tabular}

$\mathrm{U}=$ Unknown ... (A \& D Crumbles)

$\mathrm{S}=$ Standards for Tetracycline

Result $=3000 \mu \mathrm{g}$ of Tetracycline per $\mathrm{g}$ of A \& D Crumbles
Table 3 B. Quantitative analysis of antibacterial agent content in $\mathrm{A} \& \mathrm{D}$ Crumbles at an assumed content level of $500 \mu \mathrm{g} / \mathrm{ml}$.

\begin{tabular}{llllll}
\hline & \multicolumn{4}{c}{ Inhibition zones in millimeters } & Average \\
\hline U 1 & 30.5 & 30.4 & 30.8 & 30.6 & 30.6 \\
U 2 & 32.4 & 32.5 & 32.5 & 32.6 & 32.5 \\
U 4 & 34.4 & 34.4 & 34.7 & 34.3 & 34.4 \\
U 8 & 36.7 & 36.9 & 36.4 & 36.9 & 36.7 \\
S 1 & 24.1 & 25.1 & 24.8 & 24.6 & 24.6 \\
S 2 & 27.0 & 27.6 & 28.1 & 27.4 & 27.5 \\
S 4 & 29.1 & 29.8 & 29.1 & 28.8 & 29.2 \\
S 8 & 31.5 & 31.3 & 31.2 & 31.3 & 31.3 \\
\hline
\end{tabular}

$\mathrm{U}=$ Unknown ... (A \& D Crumbles)

$\mathrm{S}=$ Standards for Tetracycline

Result $=3000 \mu \mathrm{g}$ of Tetracycline per $\mathrm{g}$ of A \& D Crumbles

Table $3 \mathrm{C}$. Quantitatıve analysis of antıbacterial agent content in ADVIT at an assumed content level of $1000 \mu \mathrm{g} / \mathrm{ml}$.

\begin{tabular}{lccccc}
\hline \multicolumn{5}{c}{ Inhibition zones in millımeters } & Average \\
\hline U 1 & Contaminated & 17.8 & Contaminated & Contaminated & - \\
U 2 & Contaminated & 21.7 & 21.4 & Contaminated & - \\
U 4 & 24.3 & 23.5 & 25.7 & 25.3 & 24.7 \\
U 8 & Contaminated & 24.0 & Contaminated & 23.9 & 24.0 \\
S 1 & 24.9 & 25.1 & 24.9 & 25.1 & 25.0 \\
S 2 & 28.2 & 28.0 & 27.7 & 27.8 & 27.9 \\
S 4 & 31.1 & 30.9 & 30.8 & 30.7 & 30.9 \\
S 8 & 33.3 & 33.3 & 33.3 & 33.6 & 33.4 \\
\hline
\end{tabular}

$\mathrm{U}=$ Unknown $\ldots$. (ADVIT)

$\mathrm{S}=$ Standards for Tetracycline

Result $=130 \mu \mathrm{g}$ of Tetracycline per $\mathrm{g}$ of ADVIT

\section{Acknowledgements}

I wish to express my gratitude to Professor David G. Montefiore, Deputy Provost, College of Medicine, for providing me laboratory facilities in the Department of Medical Microbiology, University College Hospital, Ibadan, Nigeria. I am grateful to Dr. Holger Pedersen and Laboratory Technologist Anne-Marie Cornelius Moeller both of the Kemikaliekontrollen, National Agency for Environmental Protection, Copenhagen, Denmark, for their assistance on the quantitative assays and screening of test organisms.

\section{References}

Editorial: Gut as a reservoir for resistant bacteria. Lancet ii 1979, 945-946.

European Economic Community: Detection and identification of antibiotics present in animal feed stuffs by means of a bacterial spectrum. Eur. Comm. Markt Gazette 1972, 123, 71-92.

Harbour HE, Abell JM, Cavanagh P, Clegg PG, Gould CM, Ells P, Pyke M, Rilley CT, Laver $U$ Salmonella - the food poisiner. Brit. Assoc. Adv. Sci. Clumbury Cotterell Press Berkhamsted, Herts. 1978. 
Holmberg SD, Osterholm MT, Senger KA, Cohen $M L$ Drug resistant salmonella from animals fed antımıcrobials. New Eng. J. Med. 1984a, $311,617-622$.

Holmberg SD, Wells JG, Cohen ML Animal-toman transmission of antimicrobial-resistant salmonella. Investigations of U.S. outbreaks 1971-1983. Science 1984b, 225, 833-835.

Howe $K$, Linton AH, Osborne AD The effect of tetracycline on the coliform gut flora of bro1ler chickens with special reference to antibiotic resistance and O-serotypes of Escherlchia coll J. Appl. Bact. 1976, 41, 453-464.

Linton $A H$ Antibiotic Resistance. The present situation reviewed. Vet. Rec. 1977, 100, 354 360.

Ojenıy AA Epıdemiology af Avian and Human Salmonellosis and Colibacillosis in Ibadan and environs. Dr. Phil. Thesis. College of Medicine University of Ibadan, Nigeria 1980.

Quarles CL, Fagerberg DJ, Greathouse GA. Effect of low-level feeding chlortetracycline on subsequent therapy of chicks infected with Salmonella typhimurım Poult. Sc1. 1977, 56, 1674-1675.

Siegel D, Huber WG, Enloe $F$ The continuous non-therapeutic use of antibacterial drugs in feed and drug resistance of gram-negatıve enteric florae of food producing animals. Antimicrob. Agents Chemother. 1974, 6, 697-701.

Slegel D, Huber WG, Drysdale S. Human therapeutic and agricultured uses of antibacterial drugs and resistance of the enteric flora of humans. Antimicrob. Agents Chemother. 1975, $8,538-543$.
Smith $H W$ Clinical problems of preventive medicine. antibıotic resistant bacteria in animals: the dangers to human health. Brit. Vet. J. 1974, 130, 110-119.

Smith $H W \cdot$ Oral administration of neomycin to chickens experimentally infected with Salmonella typhımurım Vet. Rec. 1978, 102, 354356.

\section{Sammendrag \\ Antıbıotıkatilskud $ı$ hønsefoder. betydning for menneskets sundhed $\mathrm{l}$ de tropıske udviklıngs- lande}

En epıdemiologisk undersøgelse blandt unıversitets- og kommercielle fjerkræflokke viste antibıtıkaresistens hos $80 \%$ af Enterobacteriaceae isolater. Da fjerkræprodukter indgår 1 levnedsmidler, kan hønsene udgøre et betydeligt reservoir for humanpatogene antibiotikaresistente enterobakterier. Foderet til såvel universitets- som kommercielle fjerkræflokke hæmmede testorganismerne Staphylococcus aureus og Escherichia coll K12 J5 NA+ Lac-.

Det påvistes, at fodertilskuddene A \& D Crumbles og ADVIT, der angiveligt bestod af mineraler og vitaminer indeholdt $3000 \mu \mathrm{g}$ henholdsvis $130 \mu \mathrm{g}$ antibiotika(tetracyklin) per gram af t1lskuddet. Da disse tilskud ofte anvendes på de større fjerkræhold, kan denne praksıs føre til, at der let opstår antıbiotikaresistens hos patogene tarmbakterier, der kan overføres og besværliggøre behandling af bakterielle infektioner hos mennesker.

(Recelved March 8 1988; accepted June 26, 1988)

Reprints may be requested from: Ade A. Ojeniyi, Telemarksgade 9, DK-2300 Sundby, Copenhagen, Denmark. 
